\title{
Eugenol-rich essential oil of Anthemis mazandranica and its antibacterial activities
}

\author{
Fateme Aboee-Mehrizi ${ }^{1 *}$, Mohammad Hossein Farjam ${ }^{2}$ and Abdolhossein Rustaiyan ${ }^{1}$ \\ ${ }^{1}$ Department of Chemistry, Science and Research Branch, Islamic Azad University, Tehran, Iran. \\ ${ }^{2}$ Department of Chemistry, Firoozabad Branch, Islamic Azad University, Firoozabad, Iran.
}

Accepted 19 November, 2012

\begin{abstract}
The hydro-distilled volatile oil obtained from aerial parts of Anthemis mazandranica was analyzed by gas chromatography and mass spectrometry (GC-MS). Seventeen compounds were identified, representing $93.35 \%$ of the total oil composition, with eugenol $(35.5 \%)$ being the main component. Oil antimicrobial activity was carried out using the disk diffusion and minimal inhibitory concentration (MIC). The best antibacterial activity was observed against Salmonella Typhi with $\mathrm{ZI}=19 \pm 0.5 \mathrm{~mm}$ and MIC value of $32 \mu \mathrm{g} / \mathrm{mL}$.
\end{abstract}

Key words: Anthemis mazandranica, essential oil, antimicrobial, eugenol.

\section{INTRODUCTION}

The genus Anthemis, comprises 130 species widespread in the Mediterranean, South West Asia and South Africa (Kudryashev, 1932). Present in Iran are 39 species growing wild, among which 15 are endemic (Mozaffarian, 1996). From the Roman times up to now, Anthemis taxa have been commonly used as folk remedies, insecticides and dyes (Niko et al., 2009). Water-distilled essential oils from the leaves and flowers of $A$. altissima (L.) Var. Altissima. was analyzed by GC-MS. $\beta$-Thujone ( 33.7 and $19.7 \%$, respectively) was found as the major constituent in the leaf and flower oil (Rustaiyan et al., 2004). Over the last two decades, Anthemis volatile compounds have received more attention (Vuckovic et al., 2006; Williams et al., 2001; Vajs et al., 1999).

\section{MATERIALS AND METHODS}

Plant material and isolation procedure

The aerial parts of $A$. mazandranica growing wild in Shiraz (Provincial capital of Fars) was collected at the flowering stage in

May, 2011. Their identities were confirmed by Dr. Valiollah
Mozaffarianand and a voucher specimen (no. VS-21-13) was deposited at the Herbarium of Science and Research Branch, Islamic Azad University (Tehran, Iran).

Hydrodistillation

The air-dried aerial parts (leaves, petals and stems) (100 g) were dried, powdered and the volatile fraction was isolated by hydrodistillation for $3 \mathrm{~h}$ using a Clevenger-type apparatus. The essential oil had a bright yellow color and yielded $0.59 \% \mathrm{w} / \mathrm{w}$.

\section{GC and GC/MS analysis}

GC analysis of the oil was performed using a Shimadzu $15 \mathrm{~A}$ gas chromatograph equipped with flame ionization detector (FID) and a DB-5 fused silica column ( $30 \mathrm{~m} \times 0.25 \mathrm{~mm}$ i.d., film thickness 0.25 $\mu \mathrm{m})$. Temperature program: $60^{\circ} \mathrm{C}(3 \mathrm{~min}), 60$ to $220^{\circ} \mathrm{C}$ at $5^{\circ} \mathrm{C} / \mathrm{min}$, $220^{\circ} \mathrm{C}(5 \mathrm{~min})$; injector and detector temperatures, $260^{\circ} \mathrm{C}$; the carrier gas was $\mathrm{N} 2(1 \mathrm{ml} / \mathrm{min})$. The sample was injected in splitsplitless mode, using a split ratio of 1:50. The percentages of each component were reported as raw percentages without standardization. GC-MS analysis was carried out on a HewlettPackard 6890/5973 using an HP-5MS column $(30 \mathrm{~m} \times 0.25 \mathrm{~mm}$ i.d., film thickness $0.25 \mu \mathrm{m}$ ). The oven temperature was as above, 
Table 1. Chemical composition of leaves and aerial parts oils of $A$. mazandranica.

\begin{tabular}{lccc}
\hline Compound & $\mathbf{R I}^{\mathbf{a}}$ & Theoretical value & Aerial part (\%) \\
\hline Octane & 800 & 800 & 2.28 \\
Decane & 1000 & 1000 & 3.59 \\
a-Phellandrene & 1003 & 1002 & 3.41 \\
p-Cymene & 1025 & 1089 & 2.99 \\
limonene & 1029 & 1024 & 3.45 \\
$\beta$-Phellandrene & 1030 & 1025 & 0.61 \\
1,8-Cineole & 1034 & 1026 & 4.04 \\
Myrcenyl acetate & 1327 & 1312 & 1.88 \\
Cyclohexasiloxane, dodecamethyl & 1340 & 1330 & 18.64 \\
Eugenol & 1359 & 1356 & 35.55 \\
E-jasmone & 1402 & 1390 & 1.87 \\
$\beta$-Caryophyllene & 1419 & 1417 & 6.94 \\
Trans-a-Bergamotene & 1438 & 1432 & 2.52 \\
Y-Eudesmol & 1621 & 1630 & 3.17 \\
a-Cadinol & 1654 & 1052 & 0.72 \\
Monoterpene hydrocarbons & & & 10.46 \\
Oxygenated monoterpene & & & 59.11 \\
Sesquiterpene hydrocarbons & & & 9.47 \\
Oxygenated sesquiterpene & & & 3.89 \\
Total & & & 91.66 \\
Yield, w/w\% & & & 0.59 \\
\hline
\end{tabular}

${ }^{\mathrm{a}}$ Kovat's retention index, Tr: trace $(<0.05 \%)$.

interface temperature, $260^{\circ} \mathrm{C}$; mass range was 40 to $300 \mathrm{amu}$; scan time, $1 \mathrm{~s}$. Retention indices (RI) of compounds were determined relative to the retention times of a series of n-alkanes (C6 to C25) with linear interpolation. Identification of the oil components was done by comparison of their mass spectra with Wiley 275 GC-MS library, by comparing them with those reported in the literature and confirmed by comparison of its retention index either with those of authentic compounds or with data in the literature (Jenning and Shibamoto, 1980; Adams, 1995).

\section{Antimicrobial activity}

All test microorganisms were obtained from the Persian type culture collection (PTCC), Tehran, Iran and were as follows: Bacillus pumilus (PTCC 1319), Escherichia coli (PTCC 1533), Kocuria varians (PTCC 1484), Pseudomonas aeruginosa (PTCC 1310), Salmonella Typhi (PTCC 1609), and Listeria monocytogenes (PTCC 1298).

\section{Assessment of antimicrobial activity}

The antibacterial activity of the A. mazandranica essential oil was screened against Gram-positive and Gram-negative bacteria, with two methods:

\section{Disc diffusion assay}

Antimicrobial tests were carried out by the disc diffusion method reported by Murray and his co-worker in 1999 (Wayne, 2006). The dried $A$. mazandranica essential oil was dissolved in Dimethyl sulfoxide (DMSO) to a final concentration of $30 \mathrm{mg} / \mathrm{ml}$ and filtered through $0.45 \mu \mathrm{m}$ Millipore filters, using $100 \mu \mathrm{l}$ of suspension containing $108 \mathrm{CFU} / \mathrm{ml}$ of bacteria and $104 \mathrm{spore} / \mathrm{ml}$ of fungi spread on the nutrient agar (NA) and potato dextrose agar (PD) mediums, respectively. The discs (6 $\mathrm{mm}$ in diameter) impregnated with $10 \mu \mathrm{l}$ of the essential oil solution $(300 \mu \mathrm{g} /$ disc) and DMSO (as negative control) were placed on the inoculated agar. The inoculated plates were incubated for $24 \mathrm{~h}$ at $37^{\circ} \mathrm{C}$ for bacterial strains and 48 and 72 $\mathrm{h}$ at $30^{\circ} \mathrm{C}$ for mould isolates, respectively. Gentamicin $(10 \mu \mathrm{g} / \mathrm{disc})$ and ampicillin ( $5 \mu \mathrm{g} / \mathrm{disc}$ ) were used as positive controls for bacteria. The diameters of inhibition zones were used as a measure of antimicrobial activity and each assay was repeated twice.

\section{MIC agar dilution assay}

The lowest concentration of the compounds that prevented visible growth was considered as the minimal inhibitory concentration (MIC). MIC value of the plant essential oil against standard bacterial strains was evaluated based on the agar dilution method. Appropriate amounts of the $A$. mazandranica oil were added aseptically to sterile molten Sabouraud dextrose agar (SDA) medium added with Tween $20(0.5 \%, \mathrm{v} / \mathrm{v})$ to produce the concentration range of 8 to $500 \mu \mathrm{g} / \mathrm{ml}$. The resulting SDA agar solutions were immediately mixed and poured into Petri plates. The plates were spot inoculated with $5 \mu \mathrm{l}(104 \mathrm{spore} / \mathrm{ml})$ of each fungus isolate. At the end of incubation period, the plates were evaluated for the presence or absence of growth. Ampicillin and tetracycline were used as references for gram-positive and negative bacteria, respectively. The MIC was defined as the lowest concentration of the oil needed to inhibit the growth of microorganisms. Each test was repeated at least twice. 
Table 2. Antimicrobial activity of the aerial parts essential oil of A.mazandranica.

\begin{tabular}{lcccc}
\hline Microorganism & $\begin{array}{c}\text { MIC }(\boldsymbol{\mu g} / \mathbf{m l}) \text { of } \\
\boldsymbol{A} \text {. } \text { mazandranica }\end{array}$ & $\begin{array}{c}\text { MIC }(\boldsymbol{\mu g} / \mathbf{m l}) \text { of } \\
\text { reference }^{\mathbf{a}}\end{array}$ & $\begin{array}{c}\text { ZI }(\mathbf{m m}) \text { of } \\
\text { A. } \text { mazandranica }^{\mathbf{b}}\end{array}$ & $\begin{array}{c}\mathbf{Z} \mathbf{~}(\mathbf{m m}) \text { of } \\
\text { reference }^{\mathbf{c}}\end{array}$ \\
\hline Bacillus pumilus & 128 & 64 & $11.5 \pm 0.5$ & $16.3 \pm 0.5$ \\
Escherichia coil & 128 & 16 & $10 \pm 0.1$ & $16 \pm 0.0$ \\
Kocuria varians & 64 & 32 & $13.5 \pm 0.5$ & $17.6 \pm 0.5$ \\
Listeria monocytogenes & 512 & 16 & $6.5 \pm 0.5$ & $14.3 \pm 0.5$ \\
Pseudomonas aeroginosa & 64 & 8 & $14.5 \pm 0.5$ & $16.3 \pm 0.1$ \\
Salmonella Typhi & 32 & 32 & $19.5 \pm 0.5$ & $21.3 \pm 0.5$ \\
\hline
\end{tabular}

${ }^{a}$ Ampicillin, tetracycline were used as references for Gram-positive, Gram-negative bacteria, respectively. ${ }^{b} \mathrm{ZI}$ : Zone of Inhabitation. Including the diameter of the filter paper disc $(6 \mathrm{~mm})$; mean value of four experiments $\pm \mathrm{SD}$. Campicillin $(5 \mu \mathrm{g} / \mathrm{disc})$, gentamicin (10 $\mathrm{\mu g} / \mathrm{disc})$ were used as references for Gram-positive and negative bacteria, respectively.

\section{RESULTS AND DISCUSSION}

The oil of the aerial part contained 19 compounds with a yield of $0.59 \%(\mathrm{w} / \mathrm{w})$, representing $93.35 \%$ of the total oil composition (Table 1), where main component was eugenol (35.5\%). In particular, Oxygenated monoterpenes (59.11\%) were the most abundant group of compounds. In this study, the antimicrobial activities of the aerial parts essential oil of $A$. mazandranica were investigated against six bacterial standard strains in laboratory situation (in vitro). Antimicrobial activity (inhibition zone and MIC) of the oil against standard microorganisms is shown in Table 2. The best antibacterial activity was observed against $\mathrm{S}$. Typhi ( $\mathrm{Zl}$ and MIC value $19 \pm 0.5 \mathrm{~mm}$ and $32 \mu \mathrm{g} / \mathrm{ml}$, respectively). From a medical point of view, the antimicrobial activity of $A$. mazandranica oil against $S$. Typhi is particularly interesting because of the role of this microorganism as a pathogen agent responsible for severe typhoid fever infection.

\section{REFERENCES}

Adams RP (1995). Identification of essential oils components by gas chromatography/mass spectrometry. Allured Publishing Co, Carol Stream, IL, USA. P 456
Jenning WG, Shibamoto T (1980). Qualitative analysis of flavour and fragrance volatiles by glass capillary gas chromatography. Academic Press, New. York.

Kudryashev S (1932). Essential oils from wild plants of the central region of the Gissar Mountains. Parfums de France 12:98-101.

Mozaffarian V (1996). A Dictionary of Iranian Plant Names. Farhang Moaser publishers, Tehran, Iran.

Niko SR, Polina DB, Bojan KZ, Radosav MP (2009). Chemotaxonomically Important Volatiles of the Genus Anthemis L. A Detailed GC and GC/MS Analyses of Anthemis segetalis Ten. from Montenegro. J. Chin. Chem. Soc. 56:642-652.

Rustaiyan A, Azar PA, Moradalizadeh M, Masoudi S, Ameri N (2004). Volatile Constituents of Three Compositae Herbs: Anthemis altissima L. var. altissima Conyza canadensis (L.) Cronq. and Grantina aucheri Boiss. Growing Wild in Iran. J. Essent. Oil Res. 16:579-581.

Vuckovic I, Vuisic LJ, Vajs V, Tesevic V, Janackovic P, Milosavljevic S (2006). Phytochemical investigation of Anthemis cotula. J. Serb. Chem. Soc. 71(2):127-133.

Williams CA, Greenham J, Harborne JB (2001). The role of lipophilic and polar flavonoids in the classification of temperate members of the Anthemideae. Biochem. Syst. Ecol. 29(9):929-945.

Vajs V, Bulatovic V, Fodulovic-Savikin K, Menkovic N, Macura S, Juranic N, Milosavljevic S (1999). Highly oxygenated guaianolides from Anthemis cretica subsp. cretica. Phytochemistry 50:287-291.

Wayne PA (2006). Methods for Dilution Antimicrobial Susceptibility Tests for Bacteria that Grow Aerobically; Approved Standard, 7th Edition. Clinical and Laboratory Standards Institute.; CLSI M7-A7. 